\title{
Hedge Funds for the Middle-Class? Needs Assessment Research of SEC Mandated Accredited Investor Regulation
}

\section{Shakirov MD*}

Strategic Asset Management, Bergan Country Technical Schools, Fort Lee, NJ 07024, USA

\begin{abstract}
Individuals below a mandated threshold are prevented from investing in hedge funds (HF). The SEC regulates the HF industry. To qualify as an investor (or receiving "accredited investor" status), a person must apply through the SEC and meet financial requirements. Utilizing an indirect needs assessment, this paper will focus on the need to deregulate this legislation to allow individuals that fall below the mandated threshold to invest in HFs. This paper found that due to the performance of HFs in recessionary markets, relationship between AUM/returns, etc., non-accredited investors should be allowed to partially invest in HFs.
\end{abstract}

Keywords: Hedge funds; Accredited investor; Finance; Mutual funds; Index; Securities and exchange commission; business; AUM; Risk capacity

\section{Introduction}

The financial industry has attracted scrutiny from society due to events such as the Great Recession, and its characteristics of excessive self-interest and secrecy. Although the sentiment surrounding Wall Street has improved since 2008, finance is considered to be the least trustworthy segment of business within the United States. Still, Wall Street provides financial services to a large segment of society to help participants expand their financial growth. On the other hand, hedge funds (a financial instrument which accepts capital from "accredited investors" and utilizes leverage and short-sell tactics to create large profits) are legally prohibited from accepting capital from individuals not meeting SEC set income/net worth requirements. To protect individuals from risk-driven activities of hedge funds, the Securities and Exchange Commission imposed regulations which allow individuals with an income of at least $\$ 200,000$ and/or a net worth of over $\$ 1,000,000$ to invest in hedge funds, in order to protect an otherwise "unsophisticated" class of society [1]. Throughout this research paper, the middle-class will be defined as the group of people that fall below current "accredited investor" regulation, as described above. Therefore, this research paper will attempt to assess the need for lowered regulation of the "accredited investor" law, in order to permit the middle-class to invest their money into hedge funds.

\section{Review of Literature}

\section{Risk capacity}

The SEC cites that the risk behind hedge fund investments is too large for middle-class households to absorb [1]. Previously done research has found the principal drivers behind the risk capacity within the middle-class and how risk affects decision making. For example, financial decisions are correlated with risk aversion, the notion that people take into consideration financial losses more than financial gains [2]. Additionally, financial risk could be associated with personal attitudes or outcome aggregation, counter-arguing the SEC's idea that financial risk is correlated with wealth. The latter supports Bernoulli's "expected utility theory" [2]. Still, according to a 2003 survey study, $21.3 \%$ of respondents would be willing to sacrifice a $1 / 3$ to $1 / 2$ cut in their annual wages, for a 50/50 chance to increase their salary for the same amount [3]. This correlates with the notion that a significant portion of society has a high risk capacity. Additionally, it was found that income and value of assets affect $17 \%$ if variations within stock allocations, showing the dis-correlation between financial standing and investment decisions [3].

\section{Influx of capacity}

Under current regulation which prohibits most United States households from investing in hedge funds, the industry manages over $\$ 10$ trillion dollars after leverage [4]. The inclusion of the middle-class within hedge funds could lead to their disclosure of financial strategies, depleting their competitive advantage. Hedge funds are not mandated to release financial information, including annual reports, activity, etc., in order to maintain their "secretive" formula to success [5]. An inclusion of the middle-class in hedge fund investing could force the industry to disclose these factors and lead to depleting gains or even losses within a fund.

\section{Accredited protection}

The SEC mandates the "accredited investor" regulation in order to protect the middle-class from the financial risks associated with hedge funds. The SEC states that individuals who do not meet their "accredited" standards are financially "unsophisticated" and should not be allowed to take on the risk of investing in a leveraged financial instrument such as a hedge fund [1]. Within a historical context, a number of hedge funds with reliable track records and competent management have failed, resulting in near $100 \%$ losses of capital for their investors. For example, Long Term Capital Management, a hedge fund with Nobel-prize winning economists and a tested financial model, lost close to all investor capital after failing to account for market volatility and utilizing excessive leverage (borrowing to cover positions) [6]. Considering these examples, the SEC does not believe that the middle-class is able to risk their low net worth by investing in

*Corresponding author: Shakirov MD, Strategic Asset Management, Bergan Country Technical Schools, Fort Lee, NJ 07024, USA, Tel: + 2016651888; E-mail: davsha@bergen.org

Received June 07, 2017; Accepted September 08, 2017; Published September 15,2017

Citation: Shakirov MD (2017) Hedge Funds for the Middle-Class? Needs Assessment Research of SEC Mandated Accredited Investor Regulation. Bus Eco J 8: 317. doi: 10.4172/2151-6219.1000317

Copyright: (c) 2017 Shakirov MD. This is an open-access article distributed under the terms of the Creative Commons Attribution License, which permits unrestricted use, distribution, and reproduction in any medium, provided the original author and source are credited. 
a hedge fund that could outperform the market one year, and lose all capital the next.

\section{Financial alternatives}

Although hedge funds appear to be a risk instrument, the middleclass is not left with a large number of high-yielding alternatives. Mutual funds, accessible to a larger array of investors, attempt to mimic hedge funds without utilizing leverage or short-selling (predicting that the price of a security would go down) the market. Still, these hedged mutual funds do not offer the same performance or niche as regular hedge funds [7]. Additionally, the inability of mutual funds to short the stock market results in a significant fall in value during times of recession [8]. Although hedged mutual funds are similar to hedge funds, these financial instruments are susceptible to lower performance and a less niche trading strategy. Therefore, a middle-class individual who believes that a hypothetical hedge fund " $\mathrm{ABC}$ ” has a viable strategy, competent manager, and large returns, is unable to invest, forcing him/ her to transition to less financially prosperous mutual funds due to current regulation.

\section{Regulation flexibility}

A number of businesses have succeeded with the assistance of flexible financial and economic regulation. A case study of bKash, a mobile banking service introduced in Bangladesh, elicits the notion that under a flexible yet rational government, new ideas are able to succeed. Via a partnership with the Bangladeshi government, the creators of bKash were able to implement their idea, resulting in a fast-paced adoption of their banking platform and a creation of an accessible financial tool within an otherwise impoverished and developing community [9]. In the United States, the SEC regulations that currently restrict a large number of households from investing in hedge funds result in a potentially inflexible regulatory framework that limits the financial choices of a developed nation. On the other hand, this strict regulation could protect the middle-class from financial decay if excessive risk is taken. A large number of executives within the government, including chairmen/women of the Federal Reserve, SEC employees, etc. have been participants within the private sector (and vice versa), increasing the leverage that Wall Street has over imposed regulations [10].

Under current Securities and Exchange Commission regulation, a minority of individuals could invest in higher risk (and inherently higher return) hedge funds. Through a needs assessment research, this paper will address the gap of whether the middle-class (currently "unaccredited") should have the ability to invest into hedge funds and accept the higher risk. An analysis of whether households have enough investment alternatives, such as mutual funds, and whether they are as financially prosperous as hedge funds will be included. Additionally, the need for more capital from the middle-class will be analysed from the perspective of hedge funds, and the flexibility of current SEC regulation will be addressed. The paper will conclude with a determination of whether the regulation should be kept in place, and if not, possible solutions will be identified.

\section{Methods}

An indirect needs assessment methodology was employed within the research in order to effectively address the question/topic of hedge fund regulation in relation to the middle-class. Specifically, a needs assessment's purpose is to make "decisions about program or organizational improvement and allocation of resources [...] based on identified needs" [11]. Within this paper, an existing data approach will be utilized, which consists of using data already available from databases, sources, etc. An existing data approach uses secondary data in order to determine a need, and unlike most needs assessment approaches does not include primary data (including interviews, surveys, etc.).

In order to properly conduct a needs assessment, it is necessary to define the need within the context of the research. A need is seen as "the discrepancy or gap between "what is," or the present state of affairs, [...] and "what should be," or a desired state of affairs". This paper will evaluate whether based on the present situation (including variables such as investment alternatives, risk capacity, etc.), deregulation of the SEC law should occur in order to improve the present situation.

The indirect needs assessment will attempt to answer the main question: "Should the Securities and Exchange Commission lower its regulation on "accredited investors" in order to permit the investment of personal savings into hedge funds by households that do not meet the income requirements under current legislation?". Less complicated questions that will not be directly answered, but will be included within the paper and involved in the thought process include: "What are the financial investment needs of the middle-class?", "Could the investment techniques of hedge funds adapt to the risk capacity of the middle-class?", "What is the risk capacity of the middle-class?", and "What are the financial investment alternatives currently available to the middle-class?". These questions will be addressed in order to determine if a need is present, and if it is, possible solutions for future implementation.

An indirect needs assessment methodology encompasses multiple levels of need in order to thoroughly analyse a community's need. The levels include a Level I needs assessment, which encompasses the recipients of the assessed service, and a Level II needs assessment, which encompasses the service providers that deliver the services needed to fulfil the need for the recipients mentioned in Level I [12]. Within the context of my research, the Level I needs assessment would incorporate the middle-class, which is the recipient of the ability to invest in a hedge fund. The provider of the need for the middle-class would be hedge funds, which clearly deliver the investment services that are mentioned within this paper. Although a needs assessment is split into multiple levels, the Level I takes precedence over the rest of the groups, since they are the priority of the research [12]. Still, a need cannot be addressed if the providers of the service (Level II) are not encompassed within the research.

\section{Alternative research methods}

Before deciding to utilize an indirect needs assessment with an existing data approach, I considered other methods of conducting research. For example, I evaluated whether action research was suitable for this research paper. Eventually, I arrived at the conclusion that this methodology was not feasible. For example, action research requires that the solutions be implemented in the real world and the effectiveness of the solutions should be measured in order to gauge reliability and accuracy of the research ("Action Research Definition", 2015). This was not feasible since it is virtually impossible to implement a changed law without changing the law itself. It is equally impossible for me to change a federally-mandated financial regulation created by the Securities and Exchange Commission in the time frame provided. Therefore, I looked for a research method that encompassed the evaluative properties of action research without implementation, and arrived at the needs assessment methodology. 
The needs assessment methodology suited my research topic for a number of reasons, including feasibility and flexibility of research. For example, a needs assessment researcher chooses from a number of different approaches including an existing data, key informant, community forum, or attitude survey approach. Additionally, flexibility was provided in what kind of sources (primary or secondary) could be utilized within the research. Also, I was able to find comprehensive guides that described how a needs assessment is conducted via multiple levels, and how a need is measured quantitatively and qualitatively.

\section{Alternative needs assessment approaches}

As stated above, other needs assessment approaches were considered, while an existing data approach was chosen. The attitude survey approach was not chosen since it was not feasible to send out surveys about financial information to a large group of people that accurately represent the American middle-class. A key informant approach would not suffice since a small group of key informants would not serve as a proper representation of the American "middleclass". Other approaches, including a community forum and a focus group interview would encounter the same problems and yield unreliable data. The existing data approach allows the researcher to utilize secondary studies/data to arrive at a need (or lack thereof). This approach does not encounter the same sample size issues and gives me more resources and greater flexibility.

\section{Data}

Throughout the research paper, qualitative and quantitative data will be utilized to fulfil the requirements of the existing data approach needs assessment. Quantitative data includes the risk capacity of the middle-class (according to previously done studies), the performance of hedge fund alternatives, the growth of these financial alternatives over time, and how the size of a hedge fund affects its performance. Qualitative data includes the risk capacity of the middle-class (according to theories stemmed from behavioural economics), and how hedge funds have been historically affected by large sums under management. All data will be gathered from secondary sources, as per the existing data approach.

Sources for this research paper were gathered from databases such as JSTOR, Google Scholar, and other financial databases/publications.

\section{Findings and Analysis}

The analysis and observations section of this paper will be split into two parts, corresponding to the chosen methodology. The first part will analyse the needs of the middle-class in terms of hedge funds (Level I Needs Assessment), while the second part of the section will analyse the needs of hedge funds, in relation to the middle-class (Level II Needs Assessment). Both parts will be split into subsections, in order to analyse a number of factors pertaining to both Levels (e.g. risk capacity, hedge fund size, investment alternatives, etc.).

\section{Level I need assessment}

Investment alternatives: Individuals of a developed society face a number of financial freedoms and constraints. With little regulation present, most individuals are able to invest in stocks, bonds, real estate, and other financial instruments that rationally require deep knowledge and financial expertise. Therefore, many seek financial assistance from funds that actively manage their clients' money. For example, current middle-class individuals could allocate their capital to mutual funds (which are managed by a group of financial experts), which pool investor money (with variable minimum investment requirements usually between $\$ 1,000$ and $\$ 5,000)$ and invest in stocks and bonds without the use of leverage or short selling [7]. In contrast to hedge funds, mutual funds are strictly regulated by the Securities and Exchange Commission to follow these rules, in order to mitigate risk for investors. Additionally, mutual funds have a larger number of individual investors and are relatively liquid [13]. Hedge funds are not heavily regulated and have relatively "more flexible investment strategies" [1]. They are limited to 499 individual investors, could employ riskier investment strategies, charge higher fees, and have limited liquidity [13].

The table below summarizes the main investment alternatives available to the middle-class, in addition to hedge funds. The annualized returns and other summarized information are provided in the chart below the table. It is important to note the fee structure of each investment alternative, since these fees are taken out of profits, typically as compensation for the fund managers.

To measure the performance of hedge funds, the Credit Suisse Hedge Fund Index was chosen. This index is administered by Credit Suisse, an international investment bank, and reflects the performance of a sampled group of 9,000 international hedge funds [14]. Each fund chosen has AUM of over $\$ 50$ million, a minimum one year track record, and audited financial statements [14].

To measure the performance of a typical mutual fund, a Flexible Capital Fund was chosen. The fund is administered by Marsico Funds, a financial services corporation, and shifts from stocks to bonds based on macroeconomic conditions and financial opportunity (Flexible Capital Fund, n.d.). The fund employs riskier investment methods, at times, by investing in undervalued securities and high yield bonds (Flexible Capital Fund, n.d.) [15]. This fund was chosen since these characteristics attempt to reflect high-risk investment philosophies of hedge funds.

The S\&P 500 was chosen as a benchmark index to reflect the passive, or non-managed, returns of the American stock market. To invest in the S\&P 500, there is a large number of ETFs (electronically traded funds) available as an option for investors. These ETFs directly model the behaviour of the S\&P 500. For this research, a Vanguard S\&P $500 \mathrm{ETF}$ is used as an example index investment vehicle. The main purpose of actively managed hedge/mutual funds is to beat their benchmark index, which is typically the S\&P 500, hence its use as an alternative within this comparison [16] (Table 1).

The performance of these alternatives must also be considered in variable market conditions. Therefore, the charts and table below exemplify the behaviour of these alternatives in the 2008 Great Recession, and the subsequent upward trending market compared to their benchmark index: the S\&P 500. The table below also summarizes the total return of these alternatives from October 2007 to April 2017, after both market conditions were encountered (Figures 1-4) (Table 2).

According to the data, hedge funds provided more consistent, less volatile returns during both recessionary and expansionary periods. For example, while the benchmark S\&P index lost over half of its value during the 16 month recessionary downturn, hedge funds were able to effectively "hedge" themselves by beating the index by $32.8 \%$. This lack of volatility was also exhibited during the expansionary period, when hedge funds were able to provide returns that were lower, but more stable than the index. The flexible mutual fund, on the other hand, provided less than $1 \%$ of protection compared to the S\&P index, while exhibiting returns in-between a hedge and index fund. Still, it should 
Citation: Shakirov MD (2017) Hedge Funds for the Middle-Class? Needs Assessment Research of SEC Mandated Accredited Investor Regulation Bus Eco J 8: 317. doi: 10.4172/2151-6219.1000317

Page 4 of 7

\begin{tabular}{|c|c|c|}
\hline Name of Financial Alternative & Description/Characteristics & $\begin{array}{l}\text { Regulatory/Financial Requirements } \\
\text { to Participate }\end{array}$ \\
\hline $\begin{array}{l}\text { Hedge Fund } \\
\text { (modeled after the } \\
\text { Credit Suisse } \\
\text { Hedge Fund } \\
\text { Index) }\end{array}$ & $\begin{array}{l}\text { Actively managed } \\
\text { - Utilizes leverage (borrowed } \\
\text { money) to scale financial } \\
\text { positions and increase exposure } \\
\text { - Use of shorting tactics to } \\
\text { protect returns during recessionary periods } \\
\text { - Fee Structure (typical) } \\
\circ 2 \% \text { of total assets } \\
\circ 20 \% \text { of total profits } \\
\circ \text { The fee structure } \\
\text { fluctuates based on the } \\
\text { track record of a fund, } \\
\text { with higher performing } \\
\text { hedge funds charging } \\
\text { higher fees } \\
\text { - (Mallaby) [16] }\end{array}$ & $\begin{array}{l}\text { - Accredited by the SEC } \\
\circ \$ 200,000+\text { income, or } \\
\text { o } \$ 1,000,000+\text { net worth, } \\
\text { excluding personal } \\
\text { residence } \\
\circ \text { (Securities and Exchange Commission) [1] }\end{array}$ \\
\hline $\begin{array}{l}\text { Mutual Fund } \\
\text { (modeled after the } \\
\text { Marsico Flexible } \\
\text { Capital Fund) }\end{array}$ & $\begin{array}{l}\text { Actively managed } \\
\text { - Long-term growth of capital } \\
\text { - Unable to short securities in } \\
\text { recessionary periods } \\
\text { - Unable to use leverage } \\
\text { - Shifts from stocks to bonds } \\
\text { based on macroeconomic and } \\
\text { financial conditions } \\
\text { - Fee Structure } \\
\circ 1.37 \% \text { of total assets per } \\
\text { year } \\
\text { - (Flexible Capital Fund, n.d.) [15] }\end{array}$ & $\begin{array}{l}\text { - Does not require accredited } \\
\text { status } \\
\text { - Minimum investment of } \\
\$ 2,500 \\
\text { - (Flexible Capital Fund, n.d.) [15] }\end{array}$ \\
\hline $\begin{array}{l}\text { S\&P } 500 \\
\text { (Benchmark } \\
\text { Index) }\end{array}$ & $\begin{array}{l}\text { - Benchmark index of the } 500 \\
\text { largest publicly traded } \\
\text { corporations in the United } \\
\text { States. } \\
\text { - Could be invested in utilizing } \\
\text { index ETFs } \\
\text { - Fee Structure } \\
\circ 0.05 \% \text { of total assets per } \\
\text { year } \\
\text { (Vanguard S\&P } 500 \text { ETF } \\
\text { (VOO), n.d.) }\end{array}$ & $\begin{array}{l}\text { - Does not require accredited } \\
\text { status } \\
\text { - Minimum investment of } \\
\$ 200-300 \\
\text { - (Vanguard S\&P } 500 \\
\text { ETF(VOO), n.d.) }\end{array}$ \\
\hline
\end{tabular}

Table 1: Investment alternatives comparison

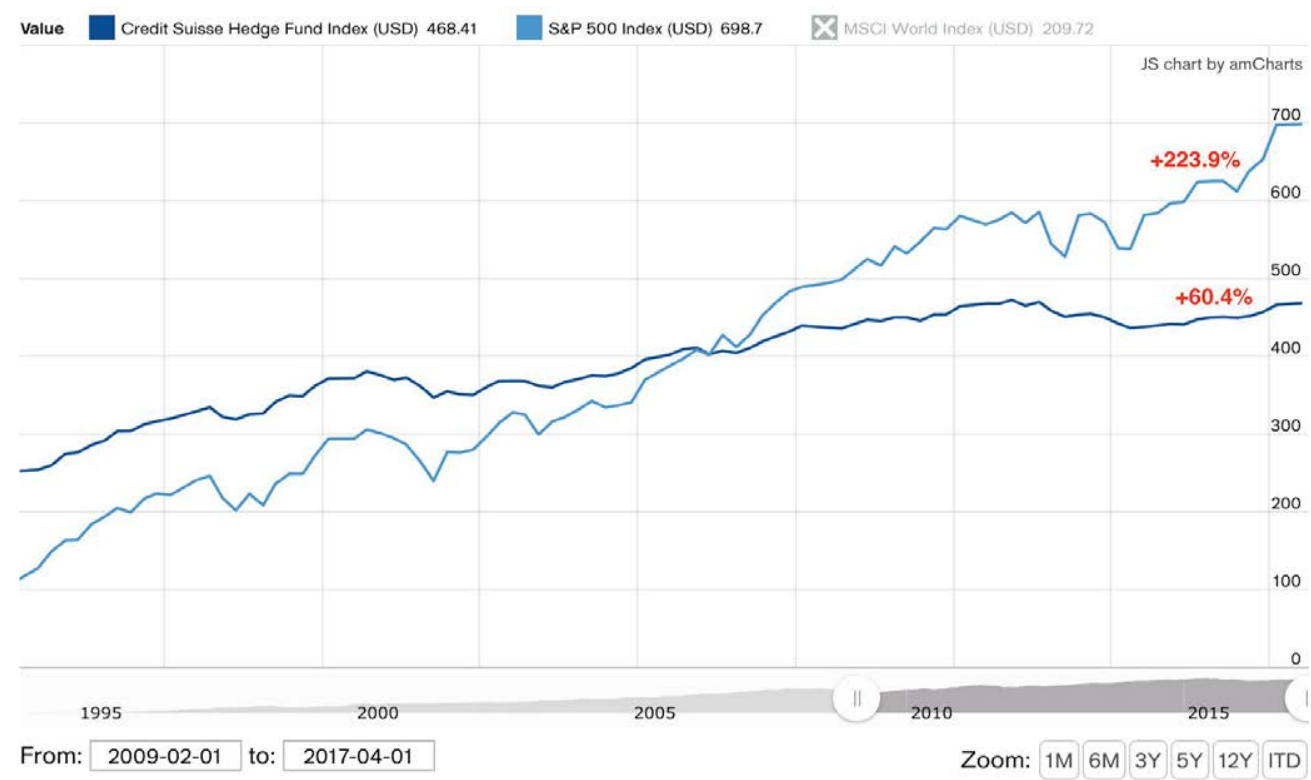

Figure 1: Upward trending market (Hedge Funds)

be noted that the flexible mutual fund was able to outperform the index by over 50\% from February 2009 to January 2014, while subsequently losing this large advantage in the next 40 months.

The SEC cites high volatility and risk when mandating the accredited investor regulation [1]. The data presented above contradicts this notion and proves that, overall, hedge funds would provide a large amount of protection in times of economic downturn during the business cycle, while continuing to provide more stable, yet smaller, returns during market expansion. 
Citation: Shakirov MD (2017) Hedge Funds for the Middle-Class? Needs Assessment Research of SEC Mandated Accredited Investor Regulation. Bus Eco J 8: 317. doi: 10.4172/2151-6219.1000317

Page 5 of 7

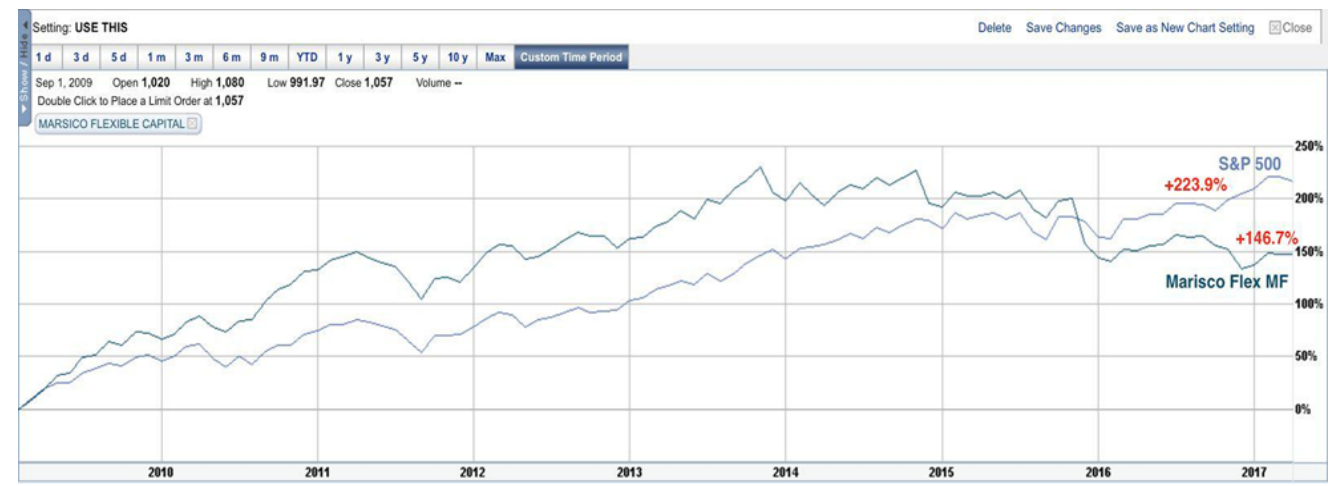

Figure 2: Upward trending market (Mutual Fund).

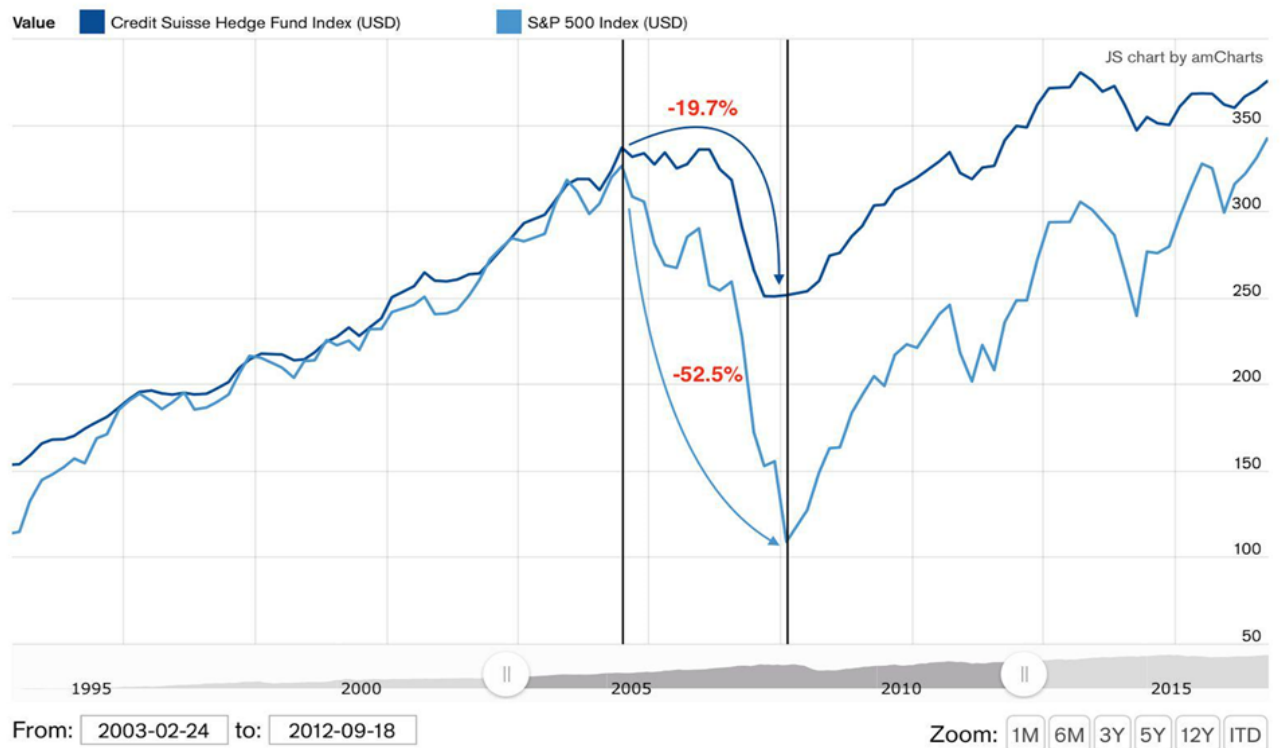

Figure 3: Downward trending market (Hedge fund).

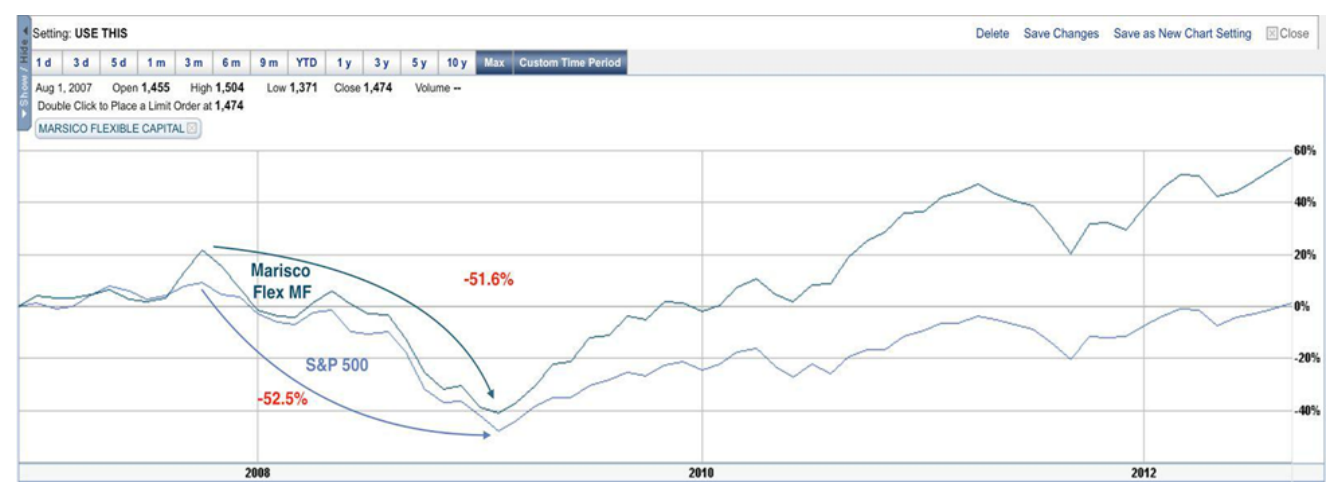

Figure 4: Downward trending market (Mutual fund).

Risk capacity: This paper will examine the risk capacity of a middleclass individual, utilizing two major studies: one that is a quantitative statistical study, and one that is a qualitative psychological paper. According to a statistical study that measured the income risk capacity of respondents over three timeframes, $21.3 \%$ of respondents agreed to take a 50/50 chance on an unbalanced outcome: either income would decrease by $50 \%$ or increase by $33 \%$ [3]. The results convey the notion that around $1 / 5$ of respondents are willing to take on excessive financial risks. The study also concluded that income affects $17 \%$ of stock allocation, based on risk [3]. This study shows that, a highly volatile 


\begin{tabular}{|c|c|c|c|}
\hline Name of Financial Alternative & $\begin{array}{c}\text { Return Over Downward Trending Market } \\
\text { (October 2007 - February 2009) }\end{array}$ & $\begin{array}{c}\text { Return Over Upward Trending } \\
\text { Market (February 2009 - April } \\
\text { 2017) }\end{array}$ & \begin{tabular}{c} 
Total Return (October 2007 - April 2017) \\
\hline Hedge Fund
\end{tabular} \\
\hline Flexible Mutual Fund & $-19.70 \%$ & $+60.40 \%$ \\
\hline S\&P 500 & $-51.60 \%$ & $+146.70 \%$ \\
\hline
\end{tabular}

Table 2: The table summarizes the total return of these alternatives from October 2007 to April 2017.

hedge fund that exhibits $50 \%$ downside and $33 \%$ upside, at least $20 \%$ of the population would have the capacity to allocate money to the fund.

From a psychological standpoint, well-established theories qualitatively prove that "risk propensity [is] ascribed to differences in the wealth" of the investors [2]. Through a comprehensive questionnaire, a study published in the Journal of Business and Psychology found that risk capacities stem from "high sensation seekers": groups of people that are prone to making high-risk decisions, independent of their financial standing. Questions asked of participants incorporated high-risk financial assets, such as stocks, bonds, and real estate, and their actions within these hypothetical situations. This connects with the notion that most risky financial decisions stem from personal characteristics, rather than income and net worth, although the latter two variables still play a role. Therefore, an individual could choose to invest in hedge funds due to their psychological characteristics, rather their SEC mandated financial standing.

\section{Level II needs assessment}

Hedge fund-industry trends: An analysis of whether hedge funds will be able to supply financial services to the middle-class if deregulation occurred is necessary to complete a Level II needs assessment. A large influx of capital into a financial instrument presents a number of challenges. For example, current regulation prohibits over 499 investors in a single hedge fund [13]. Nevertheless, by analysing the growth trends within the hedge fund industry, it is possible to conclude whether the industry would be able to absorb excess capital from the middle-class due to hypothetical deregulation. The global hedge fund industry was valued at $\$ 3.197$ trillion dollars in 2015 [17]. This compares to $\$ 416.782$ billion under management 11 years before [7]. The rapid growth could ameliorate an influx of capital from non-accredited investors, facilitating the delivery of the financial service. According to the 2016 PREQIN Global Hedge Fund Report, "fundraising could become challenging" in the next year as the number of investors with plants to decrease hedge fund investments increased in 2015 [17]. Therefore, the middle-class could ameliorate the fundraising challenge by providing funds to hedge funds that are struggling to fundraise.

Increasing-assets under management: Hedge funds are a differentiated investment vehicle due to their ability to short securities and use leverage to fund investment positions. It is necessary to analyse the effects of increasing a fund's assets under management (AUM) on returns, and whether an increase in AUM (or the number of hedge funds) leads to an immobile industry. For example, a hedge fund that has a short term investment strategy in small stocks may find it immobilizing trading with larger sums of money. Therefore, some funds may reject middle-class capital in order to bypass this issue.

According to a report published by PREQIN, which statistically analyses the correlation between hedge fund size and performance, a larger sized fund achieves similar returns, but with less volatility when compared to a smaller fund. For example, hedge funds with less than $\$ 100$ million AUM achieved an $11.45 \%$ return on average in 2013. During the same time period, hedge funds with $\$ 1-5$ billion

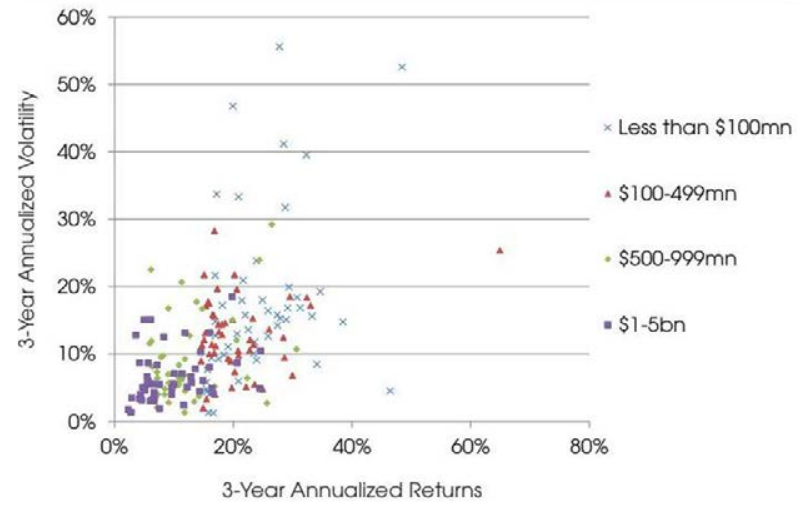

Figure 5: AUM and returns.

AUM returned a higher value of $12.08 \%$ (PREQIN, 2014). The small statistical difference is significant; since it transposes that the size of a hedge fund would not greatly affect its returns. In terms of return volatility, smaller funds have less consistent returns, while larger funds elicit the same returns with lower levels of variability. Therefore, a larger hedge fund with middle-class capital could yield less volatile and risky returns. This relationship is represented in Figure 5 below, where points representing lower AUM hedge funds are clearly more dispersed within the graph: (Figure 5).

Fee structures within hedge funds and competitors: Additionally, compensation-incentive structures within hedge funds promote an increase in AUM. Most traditional hedge funds charge fees via two channels: performance and AUM. According to a study on the incentive programs within hedge funds published in The Journal of Finance, middle-sized hedge funds charge between $0.6-1.9 \%$ of total AUM as a management fee, in addition to a $4.71-23.03 \%$ fee on total profits [18]. This structure incentivized hedge fund managers to both increase the amount of money they manage (the AUM), and increase the profits. This structure could also disincentivize losses and mitigate risk. In comparison to a hedge fund, "incentive fees for managers are extremely rare [within a mutual fund]" [19]. Therefore, the mutual fund fee-structure incentivizes profitable performance less than a hedge fund. For example, the total fees for the flexible mutual fund administered by Marsico was $1.37 \%$, compared to a typical hedge fund fee of $2 \%$ of assets and $20 \%$ of profits [20-22]. On the other hand, a large fee could also be associated with lower net profits, since the fee would haemorrhage the gains made by investors of a fund [23].

\section{Conclusion}

\section{Establishing need}

Based on the needs assessment methodology, a need must be assessed and later established within a research report. This paper considered a number of variables within the observations and analysis section, including the risk capacity and investment alternatives of the middle-class, in addition to the relationship between AUM and returns 
Citation: Shakirov MD (2017) Hedge Funds for the Middle-Class? Needs Assessment Research of SEC Mandated Accredited Investor Regulation. Bus Eco J 8: 317. doi: 10.4172/2151-6219.1000317

for hedge funds (Level I and Level II Needs Assessment, respectively). A need was established due to the data collected and its analysis.

\section{Level I}

Based on the quantitative data, a large, demographic of the American people are currently prevented from making high risk financial investment decisions (such as investing in hedge funds) [3]. From a qualitative standpoint, people's risk capacity could be determined by psychological factors, not financial ones. People with a high-risk tendency could tolerate the risk of investing in a hedge fund. Based on this variable, a need could be established. A second variable, the investment alternatives, was considered. Based on analysis of three alternatives (hedge funds, mutual funds, and index funds), the hedge fund performed best during in times of downturn, while index funds provided the best returns in times of financial prosperity. Based on this data, overall, hedge funds could be less volatile than index funds, contradicting the rationale of the Securities and Exchange Commission. Based on this variable, a need could be established.

\section{Level II}

From a Level II standpoint, the incentive structure within hedge funds would promote managers to take on extra capital from the middle-class and increase the fund's profitability. Additionally, the middle-class would increase AUM and therefore decrease volatility, as seen on the PREQIN chart, depicting assets under management. Based on this variable, a need could be established, since an expansion of the hedge fund industry could decrease volatility and incentivize profit.

\section{Further application}

By deregulating this law, the middle-class would be allowed to invest in hedge funds. This would open another alternative for them, and could increase the wealth of the middle-class, although it is more likely to be used as a vehicle to "hedge" one's finances during times of financial downfall. Although some cases of volatile, and often catastrophic, hedge fund failures are present, the hedge fund industry is generally able to effectively protect its investors during recessions. In order to bridge the present gap, and protect the middle-class from the chance of volatility of hedge funds, a hybrid approach could be created. The approach could incorporate weighted averages to allow individuals to only accredit portion of their assets by the SEC. For example, categories including years from retirement, net worth, income, and other factors could be assigned weights, and a coefficient can be calculated. This would determine that an individual, while middle-class, could contribute an X\% of his/her net worth to a hedge fund. Through this approach, the middle-class could be partially hedged from volatile hedge funds and (during times of macroeconomic downturn) from a depressed financial environment.

For future research, a study that incorporates multiple mutual funds for comparison may yield worthwhile results. Additionally, an examination of particular hedge fund strategies (arbitrage, distressed equity, long-short, etc.), and which one would work best for the middle-class, would be valuable. Finally, a needs assessment of the laws surrounding mutual funds could be accomplished in order to evaluate their legal restrictions and differentiations from hedge funds.

Hedge funds have grown dramatically over the last four decades. Still, this growth has been fuelled by high-net-worth individuals, "accredited" by the SEC to invest in high-risk financial instruments like hedge funds. In an effort to democratize the financial markets, the SEC should consider changes to SEC Rule 501 of Regulation D - Accredited
Investor Regulation in order to incorporate middle-class investors in new financial endeavours.

\section{References}

1. United States of America, Securities and Exchange Commission.

2. Corter JE, Chen Y (2005) Do Investment Risk Tolerance Attitudes Predict Portfolio Risk? Journal of Business and Psychology 20: 369-381.

3. Kimball MS, Sahm CR, Shapiro MD (2007) Imputing Risk Tolerance from Survey Responses. Journal of the American Statistical Association 103: 10281038.

4. Fichtner J (2011) Financialization: The Role of Private Equity and Hedge Funds

5. Donaldson T (2008) Hedge Fund Ethics. Business Ethics Quarterly 18: 405-416.

6. Furfine C (2006) The Costs and Benefits of Moral Suasion: Evidence from the Rescue of Long-Term Capital Management. SSRN Electronic Journal.

7. Agarwal V, Boyson NM, Naik NY (2016) Hedge Funds for Retail Investors? An Examination of Hedged Mutual Funds. Journal of Financial and Quantitative Analysis 44: 273-305.

8. Kao D (2002) Battle for Alphas: Hedge Funds versus Long-Only Portfolios Financial Analysts Journal 58: 16-36.

9. Chen G, Rasmussen S (2016) BKash Bangladesh: A Fast Start for Mobile Financial Services.

10. Johnson S (2009) The Quiet Coup.

11. Witkin BR. Altschuld JW (2006) Planning and conducting needs assessments: a practical guide. Thousand Oaks, Calif.: Sage Pub.

12. Altschuld JW, Kumar DD (2010) Needs Assessment: An Overview. Sagepub.

13. Kennard A (2003) The Hedge Fund Versus the Mutual Fund. The Tax Lawyer 57: 133-161.

14. https://lab.credit-suisse.com/\#/en/index/HE\%20DG/HEDG/performance

15. Marsico Funds - Flexible Capital Fund.

16. Mallaby S (2010) More money than God: Hedge funds and the making of a new elite. New York: Penguin Press.

17. Preqin (2016) Global Hedge Fund Report. Newyork.

18. Altschuld JW, Witkin BR (1999) From Needs Assessment to Action: Transforming Needs Into Solution Strategies. Sagepub.

19. Action Research Definition

20. Beyer G (2014) Want To Make A Difference? Don't Be A Hedge Fund Manager 21. Cassidy J (2011) Mastering the Machine.

22. Does Fund Size Affect Hedge Fund Performance?

23. Edelman Trust Barometer. 